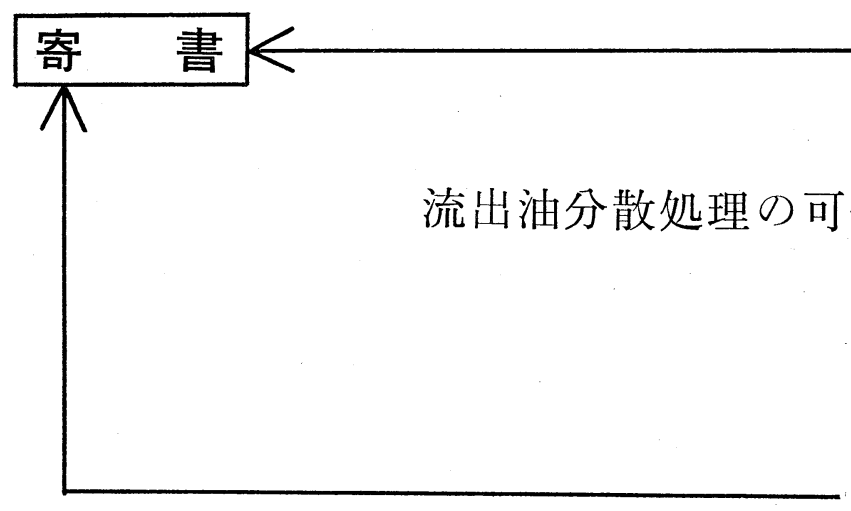

$\begin{array}{ccccc}\text { 神戸商船大学 } & \text { 近 } & \text { 藤 } & \text { 五 } & \text { 郎 } \\ & \text { 橋 } & \text { 本 } & & \text { 武 } \\ & \text { 西 } \text { 田 修 } \text { 身 }\end{array}$

\section{1.はしがき}

先般来新潟 (11月30日) をはじめとして, 西宮 (10 月19日), 神戸 (12月20日), 山口県 (12月9日), 東 京湾 (12月10日) などの各地沿岸でタンカー事故によ る流出油事故が立てつゔけに抽っている。

海上に石油が流出した時, この油を捕集回収する か, または燒却消去する方法が海洋環境の保全の目的 から考えると最も理想的であり,「比較的荒天下でも 流出油を捕集しらる装置を設備し, 同時に焼却処理方 法を検討し，このような合理的な処理法を事故海上で 有効に実施するための技法の研究と訓練とを行ならこ とが急務である」ことは当然である。しかし事故のお こる海域はややもすれば気象条件が非常覀く, きめ の細かい作業を要する上述のような処理作業は現実に 実施できない場合がある。そこでこのような場合に， 比較的簡易な作業で実施できるための分散処理法が利 用される。

ところが今回の新潟における事故対策において, 一 部の生態学者グループから, 処理剤の毒性が 2 次公害 をおこすとして，海上保安庁にその使用中止を申し入 れた ${ }^{1}$ 。筆者は現在の処理剤の一部のものはトリ・キ ヤニオン号事件当時の処理剤に比べてはるかに毒性が 低いことを指摘した ${ }^{2)}$ が，一方なお処理剂の毒性が報 じられている3

そこでこの機会に流出油の挙動, 処理剤の実態など についてのべ，ついで流出油分散処理法の可否を論じ るべき正確な焦点を提示するものである。

\section{2. 流出油の挙動}

流出した油は海面に拡散すると同時に風潮の作用に より漂流するが, 流出油の分散処理の可否論に直接関 係が深いと思われる流出油の 2,3 の化学的な挙動に ついてのべる。

2-1 流出油の蒸発
流出油が原油である場合, 油は流出後拡散すると同 時にその低沸点成分はすみやかに気化蒸発する。その 速度は油の成分の蒸気圧によるよりもむしろ流出油面 に吹きつける風の速さによる影響が大きく, 荒天の場 合は海面の油は空中にとび散って, 蒸発速度は著しく 促進される。比較的平穏な海面でも低沸点の引火性ガ スの蒸発速度は大きく, 現に昭和 43 年八大島近海で科 学技術庁が行なった実験結果 ${ }^{5)}$ によると, 水温気温之 も $25 \sim 27^{\circ} \mathrm{C}$, 風力 2 の状態で約 $100 \mathrm{k} l$ のイラニアン ヘビー原油を流出し, 流出油附近の海上 $70 \mathrm{~cm}$ の点で 引火性ガスの濃度を測定した結果, 引火性ガスが検知 されたのは最初の 25 分間で, それ以後は全々検知され なかった。

また筆者らの実験によると径 $30 \mathrm{~cm}$ の管内に浮上さ せた $10 l$ の原油（ミナス，マーバン，イラニアンへビ 一, クェートおよびカフジ) 中ミナス原油以外のもの は 6 月 8 月の夏季において, $\mathrm{C}_{12}$ 以下の炭化水素は 約90日でほとんど気化蒸発している。

したがって, 気化蒸発してしまう成分中の有害物質 は長時間の拡散または漂流中に大気中に消失して, そ の分だけ海洋生物に被害をあたえる度合が軽減するこ とが考えられる。

2-2 流出油のエマルジョン化 ${ }^{4}$ (オイルボールの生 成)

海上に流出した油は意外に早くエマルジョン化す る。そして水中油滴型のエマルジョンは後述の流出油 処理剤を添加しなければ生成しにくいが，油中水滴型 エマルジョンは容易に生成し，20 80\%の海水滴を含 有した油塊となる。

この油塊は, トリ・キャニオン号事件当時いわゆる “Chocolate mousse” (日本ではオイルボールとよば れている）とよばれ，後述の処理剂によっても容易に 乳化分散しない厄介なものである。そしてたまたまそ 
の比重が海水より大きくなったものは海没し，1965年 におこったアンネブロビヒ号の 2 万トンの流出油の行 方不明事件 ${ }^{6}$ の原因注この現象による可能性が大きい とされている。

いずれにしてもこのオイルボールは長期にわたって 観光的な損失と海面または海底生物に大きな被害とを あたえるものである。

2-2 流出油の化学変化

流出油に起こる化学的変化注酸化反応と, 生物化学 的な消化作用である。酸化反応は, もちろん大気中の 酸素によるもので, 海水はもちろんその深度による差 はあるが, 表面水で約 $8 \mathrm{mg} / l$ の酸素を溶解しており, $4 \times 10^{5} l$ の海水は $1 \mathrm{~m} l$ の油を酸化するに要する酸素を 含んでいるて。

油の酸化は炭化水素の遊離基生成による自己酸化で あり ${ }^{8} ， 3$ 級炭素， 2 級炭素， 1 級炭素の順で酸化さ れやすい。さらに共鳴構造をとるテトラリン，キュメ ンといった成分の自己酸化はさらに迅速となる。その 上, 日光による光学的な酸化も複雑にからんでくるも ので，この場合はバナジウムのような多原子価を取る 金属の存在が，酸化を促進し，硫黄化合物が抑制的に 働くとされている。

炭化水素が酸化した時は, 有機酸, カルボニル化合 物, アルコール, パーオキサイド，スルフォキサイド などを生成して, 水溶性となり, 一部界面活性剤的 な性質を示して, 油を分散しながら海水中に溶出す る)。

生化学的変化は海水中に存在する微生物により起こ る変化であり, その速度は溶存酸素, 栄盖分, 水温な どにより決るが, Zobell は $50^{\circ} \mathrm{F}$ に招いて $8 \times 10^{6}$ 個/ $\mathrm{m} l$ のバクテリヤ密度で約 $1 \mathrm{~g} /$ 日の酸化速度であると しており ${ }^{6)}$, したがって, 微生物による変化は時間的 には日よりむしろ月単位で考えられるものである。そ して, 油の微生物による消化は 3 級炭素上り 1 級炭素 の順に困難さが低下するのに反して, 前述の酸素によ る化学的酸化作用はこれと反対に 3 級炭素のほうが 1 級炭素より酸化されやすく, 両者の作用が相呼応し て,ついには炭化水素が完全に分解されてしまうとさ れている。

この化学的酸化と生物的消化との総合作用がいわ沛 る自然浄化作用であり, 油滴の表面積は油滴径の 2 乗 に比例するから, 微粒油滴の自然浄化速度はかなりの 大きさが期待される。

\section{3. 分散処理と処理後の油の挙動}

流出油を分散処理した場合, 当然処理剂と流出油自
体との環境に及ぼす影響を考慮しなければならない。 そこで今, 処理剤の実態, 処理剤の撰択および乳化分 散と流出油の毒性の 3 項について記述する。

\section{3-1 処理剤の実態}

筆者は昭和 42 年度の科学技術庁の「巨大タンカーの 油流出事故対策に関する特別研究」において, 流出油 の化学処理に関する研究分野を担当し, 主として処理 剤の性能, 毒性などについて検討し9，さらに処理剤 の改良研究を行なっており ${ }^{10)}$, 現在に至るまでの処理 剤の実態を正確に把握しているので，ここにその内容 をのべる。

1）処理剤の歴史

流出油処理剤なるものが市販されたのは約15年前で あるが，トリ・キャニオン号事件に多量の処理剤が用 いられて以来, 世間の注目を浴びたものである。

この事件に関する英国政府の報告 ${ }^{11}$ によると，事件 当時陸上施設または機械の油によるよごれを洗浄する ために製造されたギャムレン（商品名）などの油洗浄 剤を急きょ使用したものである。したがってこの洗浄 剂は洗浄效果のみを主目的にして製造されたもので, その対生物毒性については考慮されていなかったとい う見方も可能である。

そして当時処理郕の影響については使用した量が広 さ20マイル平方, 梁さ10フィートの海域に拡散し, そ の濃度が 1ppm 以下になるので海洋環境を害するもの ではないとされたが，後になって処理剤を用いた海域 で多くの野鳥がへい死し, また海生動物が著しく死滅 したことがわかった。

事実当時用いた洗浄剤の組成は表 1 亿示すように， その主成分である界面活性剂はともかく, 毒性の強い 芳香族炭化水素を多量に含有していた。

\section{表 1 トリ・キャニオン事件に用いられた 処理剂の組成}

$\begin{array}{lcc}\text { 品 名 } & \begin{array}{c}\text { 活 性 剂 } \\ \text { 量 }\end{array} & \begin{array}{c}\text { 溶剂中の苏化 } \\ \text { (\%) }\end{array} \\ \text { BP } 1002 & 20 & 16 \\ \text { Dasic } & 25 & \text { 多 } \\ \text { Gamlen } & 30 & 24 \\ \text { Dutch } & - & - \\ \text { Atlas } & 30 & 8 \\ \text { Petrofina } & 8 & 15 \\ \text { Basol } & 15 & 82 \\ \text { Gramos } & - & - \\ \text { そ の 他 } & - & -\end{array}$


表 2 トリ・キャニオン事件に用いた 処理剂の毒性

処 理 剂 供試動物 半数以上致死する濃度
$(\mathrm{ppm})$ (試験時間 hr)

(1)

(8)

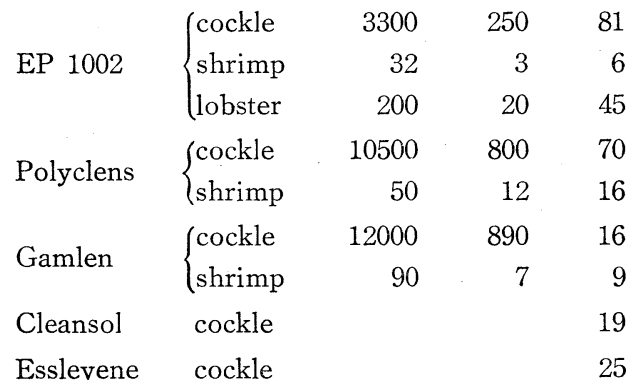

そしてこれらの油洗浄剤の対生物毒性は表 2 に示す ようにかなり毒性が高いことがわかった。

一方当時わが国でもすでに流出油処理剤は実用され ており,その種類として

(1) 流出油分散剤……流出油を乳化分散させるもの

(2) 流出油沈降剤……流出油の比重を海水のそれよ りも大きくして沈降させるもの

の 2 種があった。そして沈降剤としてはパークロルエ チレン（比重1.62）そのものが用いられており，この ものはその毒性と海底の污染の問題とから当時すでに あまり実用されておらず，現在では全々市販さえされ ていない（処理剤を用いると油が海底に沈降するとい らのは，この辺の事情を知らないものの説である)。

2) 流出油処理剂の検討と改善

前述の科学技術の特別研究において, 筆者らは昭和 43年 4 月現在の市販処理剂16種（らち3 種は外国品） について, その性能, 毒性などについて試験し9), つ いで低毒性処理剤の開発研究を行なった ${ }^{10)}$ 。その結果 判明した $2 ， 3$ の点をつぎにのべる。

(a) 処理剤の流出油処理状況を分類すると, 油を海 面に散らせる型（表面拡散型）と油を微粒にして 海水中に乳化させる型（乳化分散型）とがある。

(b) 対魚類急性毒試験を行なった結果, 処理剤の濃 度を $15 \mathrm{ppm}$ とし10匹の供試魚 (金魚)の経時的 な生存数は表 3 に示すように，市販品16種中毒性 が低いと判断されるものは 4 種であり, そのらち 3 種は表面拡散型のものであった。

(c) 流出油処理剤の主成分である各種の界面活性剂 の毒性を試験した結果は表 4 に示すようにエステ ル型非イオン界面活性剂が低毒性である。
表 3 市販処理剂の毒性（昭和 43 年 4 月）

\begin{tabular}{|c|c|c|c|c|c|c|}
\hline \multirow{2}{*}{ 処理剤 } & \multicolumn{2}{|c|}{ 最初の水の状態 } & \multicolumn{2}{|c|}{ 生 存 } & \multicolumn{2}{|c|}{ 魚 数 } \\
\hline & $\mathrm{pH}$ & $\begin{array}{c}\text { 溶存酸素 } \\
\text { (ppm) }\end{array}$ & $2 \mathrm{hr}$ & $4 \mathrm{hr}$ & $6 \mathrm{hr}$ & $24 \mathrm{hr}$ \\
\hline A & 8.46 & 8.4 & 9 & 0 & & \\
\hline $\mathrm{C}$ & 8.93 & 8.5 & 7 & 1 & 0 & \\
\hline $\mathrm{D}$ & 8.37 & 8.5 & 10 & 10 & 10 & 10 \\
\hline $\mathrm{E}$ & 8.36 & 8.4 & 10 & 10 & 8 & 2 \\
\hline $\mathrm{F}$ & 7.85 & 8.4 & 6 & 1 & 0 & \\
\hline G & 7.78 & 8.5 & 10 & 9 & 6 & 3 \\
\hline $\mathrm{H}$ & 8.55 & 8.4 & 10 & 10 & 10 & 10 \\
\hline $\mathrm{I}$ & 8.61 & 8.4 & 10 & 5 & 0 & \\
\hline$J$ & 9.04 & 8.5 & 10 & 10 & 10 & 10 \\
\hline $\mathrm{K}$ & 8.65 & 8.6 & 10 & 10 & 10 & 7 \\
\hline $\mathrm{L}$ & 8.95 & 8.5 & 10 & 10 & 10 & 10 \\
\hline M & 8.55 & 8.6 & 10 & 10 & 10 & 0 \\
\hline $\mathrm{N}$ & 8.18 & 8.5 & 10 & 9 & 6 & 1 \\
\hline $\mathrm{O}$ & 8.95 & 8.4 & 10 & 10 & 9 & 0 \\
\hline $\mathrm{P}$ & 8.70 & 8.5 & 10 & 10 & 10 & 7 \\
\hline
\end{tabular}

\section{表 4 界面活性剂の無毒限界}

界 面 活 性 剂無毒限界

$$
\begin{aligned}
& \begin{array}{l}
\text { ポリオキシェチレンラウリルエーテル } \quad<10 \\
\text { (エチレンオキサイド } 4 \text { mol付加) }
\end{array} \\
& \text { "l (" } 47 \text { " " } 60 \sim 70 \\
& \text { ポリオキシェチレンオレイルエーテル <20 } \\
& \text { "l (" } 20 \quad \text { " } \quad 40 \sim 50 \\
& \text { ポリオキシエチレンノニルフェノール } 10
\end{aligned}
$$

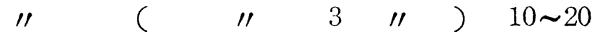

$$
\begin{aligned}
& \text { "l ( } \quad \begin{array}{lllllllll}
\prime \prime & 20 & \prime \prime
\end{array} \\
& \text { ソルビタンモノステ゚アレート }
\end{aligned}
$$

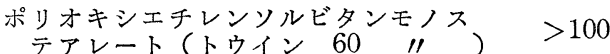

$$
\begin{aligned}
& \text { ポリエチレングリコールラウレート > }>100 \\
& \text { "I オレート >100 } \\
& \text { アルカノールアマイドー20〜30 } \\
& \text { ブロックポリマーー>100 } \\
& \text { D.B. }{ }^{3)} \quad 10
\end{aligned}
$$

（d）希釈剤に用いる有機溶剤の毒性については芳香 族化合物が毒性が高く，これがトリ・キャニオン 号事件で海生動物に大きな被害をあたえた原因の 一つと思われる。

3）現在の市販処理剤の毒性 
以上の研究成果洺くの処理剤メーカーに利用さ れ，その製品が改造されたため, 昨年 4 月海上保安 庁, 日本海難防止協会上りの依頼で, 昭和 46 年 4 月現 在の市販品（17社34種）について再度その性能, 毒性 について試験した。その毒性試験は処理剤の濃度を $50 \mathrm{ppm}$ と，24時間後の生存魚数を記録した結果，表 5 に示すとおり致死魚のないものは34種中11種あり， 流出油処理剤の毒性は 3 年間で著しく改善されている ことがわかる。

表 5 魚類による急性毒試験（昭和46年 4 月）

$1 \mathrm{hr} \quad 2 \mathrm{hr} \quad 3 \mathrm{hr} \quad 4 \mathrm{hr} \quad 5 \mathrm{hr} \quad 24 \mathrm{hr}$
(7)$$
\text { × }
$$$$
\text { オ }
$$$$
\text { (a) }
$$

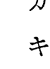$$
\text { , }
$$$$
\text { s }
$$$$
=
$$

H

$$
\text { s }
$$$$
\text { t }
$$

$$
\oplus
$$

\section{$(7$}$$
0
$$

$$
\text { 永 }
$$

\footnotetext{
供試魚: 和金 体長: $5 \sim 7 \mathrm{~cm}$ 平均体重: $3.5 \mathrm{~g}$
} 処理剤濃度 : $50 \mathrm{ppm}$

\section{3-2 処理剤の選択}

流出油を分散処理する時, 用いる処理剤は当然可及 的に低毒性のものを撰択しなければならない。そして 今回の新潟事故のニュースから, 今後の問題点として つぎの 2 点があげられる。

(1) 市販処理剤の毒性はここ 3 年間かなり改善され ているが，なおいまだに毒性の強いものもある。

(2)処理剤の現地への輸送にかなりの時間を要す る。

この 2 点を考慮するとつぎの方策が合理的である。 すなわち，とくに毒性の低いエステル型非イオン界面 活性剤（具体的には牛脂脂肪酸ポリエチレングリコー ルエステル300４00）そのものを処理剤に用いる。

幸い牛脂脂肪酸ポリエチレングリコールエステル 300〜400は粘度は高いが高圧スプレーガンで散布する ことができるし，もちろんこれを灯油に20\%位溶解す れば粘度は低下して散布しやすくなる。ただしこの際 用いる灯油垱然芳香族炭化水素の少ないパラフィン 系炭化水素よりなるものを選択使用しなければならな い。

上述のように原材料を処理剤として用いると処理剂 自体の低毒性は保証され, 現地でパラフィン系灯油で 希釈すれば, 輸送量が現在の $1 / 5$ となる。

なお, 牛脂脂肪酸ポリエチレングリコールエステル 300 400の流出油乳化分散能は表 6 に示すように, 市 販処理剤の性能に劣らないと思われる。

\section{3-3 乳化分散と流出油の毒性}

処理剤を適正に散布することは実際上非常にむずか しい。なぜならば流出油の層の厚さはかならずしも一 定していないため, 厚い油層に対しては, ややもすれ ば散布量が不足し, 油層が薄い時は処理剤が海中に射 出され, 肝心な油の乳化分散が行なわれず, 表面拡散 性能が支配的になり, 海面の油を散布点から押しのけ るにすぎない。

理論的にいって, 適量以上の処理剤がよく流出油と 混和したのち海水と混合し, まず油中水滴型エマルジ ヨンを生成し, これが海水の混合量の増大によりつい には水中油滴型に相の転換がおこる。この時に油は超 微粒化して理想的な乳化分散状態になる。

このように微粒化した油滴は沈降も浮上もせずに, 海面近くの海水中に安定に乳濁しており，次第に搪散 する。

このよらな状態の油の毒性については表 7 のとおり 報告されている12)が, 油滴と海水の接触面積は非常に 大きく，そのために，これに対する $2-2$ にのべた自然 
表 6 市販処理剤と脂肪酸エステルとの油乳化能

処理剂または界面活性剂

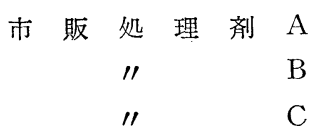

ポリエチレングリコールオレート

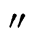

"l

II

ポリエチレングリコールステアレート

"I

"I

"I

市販処理剂の主成分

"l

II

牛脂脂肪酸ポリエチレングリコールエステル

"l

表 7 分散油の毒性

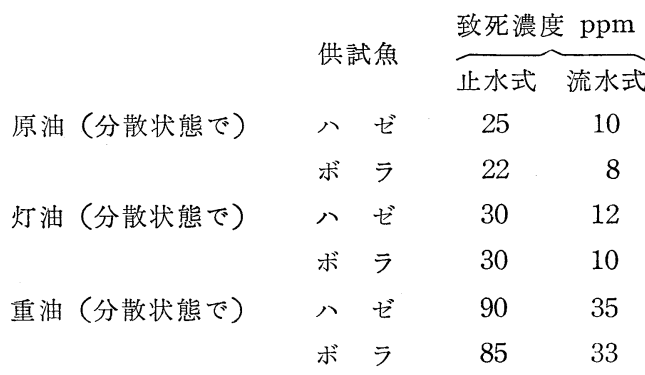

浄化作用は予想外に早い。ただ C 重油のような粘度の 高い油には処理剤がよく混和しないため, 処理剤の乳 化分散能は著しく悪い。

\section{4. 分散油と浮上油との毒性試験}

筆者はかねてから現在の市販処理剤の一部のものは その毒性が低くく，海生動物への被害の原因にはなら ないと考えていた。そこで今回の事故後, 急拠処理剤 を一切用いないで，分散油と浮上油との毒性 JIS 0102 をに準じて実験した。以下にその内容をのべる。 [供試魚] 金魚, 体長 $4 \sim 5 \mathrm{~cm}$, 体重 $1.5 \sim 2 \mathrm{~g}$

〔分散油]家庭用ミキサーのカップに $1 l$ の水を入 れ，全速でかきまぜながら $1 \mathrm{~g}$ の鉱油（A重油と沸 点150 $200^{\circ} \mathrm{C}$ のパラフィン系炭化水素) を投入し, 30 分かきまぜ続け, 含油量 $10,000 \mathrm{ppm}$ の分散油と した。この分散油の油滴の径は顕微鏡写真より平均

\begin{tabular}{|c|c|c|}
\hline \multicolumn{2}{|c|}{ 乳 化 率（\%） } & \multirow{2}{*}{$\begin{array}{c}\text { 乳化安定度 } \\
(\%)\end{array}$} \\
\hline 30 秒後 & 10 分後 & \\
\hline 96.0 & 60.0 & 62.5 \\
\hline 100.0 & 36.0 & 36.0 \\
\hline 88.0 & 16.0 & 18.1 \\
\hline 75.9 & 42.4 & 55.9 \\
\hline 88.3 & 81.2 & 92.0 \\
\hline 84.8 & 63.6 & 75.0 \\
\hline 67.1 & 35.3 & 52.6 \\
\hline 0 & - & - \\
\hline 0 & - & - \\
\hline 44.1 & 0 & 0 \\
\hline 0 & - & - \\
\hline 84.8 & 60.0 & 70.8 \\
\hline 75.9 & 37.1 & 48.8 \\
\hline 74.2 & 42.4 & 57.1 \\
\hline 90.0 & 83.0 & 92.2 \\
\hline 90.1 & 68.9 & 76.5 \\
\hline
\end{tabular}

$2 \sim 3 \mu$ とみなされた。

[対魚類急性毒試験]

i）水槽に $10 l$ の 50 500ppm の油を含む分散油含 有水を調製し，各々の槽に10匹ずっの供試魚を入 れ，エヤーポンプで送気する。水温は $22 \sim 25^{\circ} \mathrm{C}$ で ある。

ii）水槽に $10 l$ の水と供試魚とを入れ，200 500 ppm に相等する重油を水面に浮かべ，i）と同様 送気する。

[実験結果]

経過時間による供試魚の状況を表 8 に示す。

この結果から，明らかに分散油は浮上油よりもはる かに魚類に有害であり, 分散油でもパラフィン系炭化 水素は無害である。

したがって，この事実から流出油自体の毒性を考慮 すれば, 流出油の分散処理において分散油の毒性を軽 々しく処理剂に結びつけることは当をえていない。

\section{5. 流出油の環境におよぼす影響}

流出油の分散処理の可否を論じるためには, 分散処 理を行なって乳化分散した状態の油と流出油をそのま ま放置して浮上した油との環境に及ぼす影響を比較検 討しなければならないが，さしあたって分散油と浮上 油との環境に及ぼす影響を推定すればつぎのとおりで ある。 
表 8 経過時間による供試魚の状況

\begin{tabular}{|c|c|c|c|c|c|c|c|c|}
\hline \multicolumn{2}{|r|}{ 触油と状態 } & 濃度 (ppm) & $4 \mathrm{hr}$ & $20 \mathrm{hr}$ & $24 \mathrm{hr}$ & $30 \mathrm{hr}$ & $48 \mathrm{hr}$ & $72 \mathrm{hr}$ \\
\hline \multirow[b]{2}{*}{ 分 } & A & 50 & - & - & - & - & - & - \\
\hline & 重 & $\begin{array}{l}100 \\
150\end{array}$ & - & - & - & - & - & - \\
\hline 散 & 油 & 200 & - & $\triangle-2$ & $\triangle-5$ & $\triangle-2$ & $\overline{\Delta-2}$ & $\triangle-2$ \\
\hline 油 & & 500 & $x-10$ & & & $x-3$ & $x-3$ & \\
\hline & 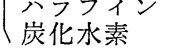 & 500 & - & - & - & - & - & $\ldots$ \\
\hline & 上油 (A 重油) & 200 & - & - & $\longrightarrow$ & $\triangle-2$ & $\triangle-2$ & $\triangle-3$ \\
\hline & & 500 & 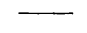 & - & $\triangle-2$ & $\triangle-2$ & $\Delta-2$ & $\triangle-2$ \\
\hline
\end{tabular}

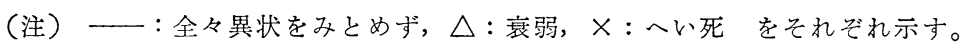

浮上油（流出油放置の場合）

1）海岸線は長期にわたって污染され, 観光価值を 損なら。

2）流出油が広大な海面に拡がり, 海面生物（ノリ など）の被害は大きい

3）オイルボールが生成しやすく, 場合によっては 油塊として海底に沈降し, 海底生物に被害を与え る。

4) 魚類野鳥のような移動する海生物は油害を忌避 することも可能である。

5）流出油は浮上中に低沸点有害な成分が気化し, その分だけ毒性は軽減する。

分散油（分散処理した場合）

1) 海岸線の污染は比較的早く洗浄される。

2) 海面下数 $\mathrm{m}$ の海水は一時的に著しく污染される が, 污染海水は比較的早く拡散し, 油分は自然浄 化され，環境の復元は早い。

3）海面生物の被害の及ぶ面積はかなり局限され る。

4）流出油の低沸点有害成分は気化することなく全 部海水中に移行する。

\section{6. 総括と今後の問題}

以上, 要約すれば, 流出油の分散処理の可否につい ては, 現在批判のまとになっている処理剤の毒性より も, むしろ浮上油層と分散油滴との海洋環境に及ぼす
影響を詳細に比較検討した上で論じなくてはならな い。

この意味で分散原油の留分別による対海生動物毒 性, 分散油の海域に打ける抬散状況, 海岸線の分散油 および浮上油による污染の回復の早さの比較などにつ いて早急に検討すべきである。

\section{文献}

1) 朝日新聞, 昭和 46 年 12 月 4 日

2) 11, 同 8 日

3) 11, 同 9 日

4) S.A. Berridge \& R. A. Dean, The Properties. of Persistent Oils at Sea, Journ. of the Inst of Pet., Nov., 1968

5) タンカーの油流出事故対策に関する特別研究報告 書, 昭 44.3 (科学技術庁)

7) C.E. Zobell, Inst. of Air Wat. Poll., 7, 173 (19 63)

8) A. Robertson, Journ. of Chemical Soc., 1574, 1578, 1585 (1968)

9) 近藤ほか, 油化学, 18, 673 (1969) : 火災, 19, 72 (1969)

10) 近藤ほか, 大阪工業技術試験所季報, 21, 13 (19 70)

11) The Torry Canyon (Her Majesty's Stationary Office) 1967 


\title{
About the Propriety of Dispersing Method for Spilled Oil on Sea
}

\author{
by Goro Kondo, Takeshi Hashimoto \& Osami Nishida
}

(Kobe Merchantile Marine University)

SYNOPSIS:-At the treatment of spilled oil on sea, dispersing method using oil dispersers is frequently applied and the toxicity of oil disperser has been called in question. We studied on the toxicity of marketed oil dispersers and some of them were found to be almost non-toxic.

We also studied on the toxicity of oil itself and found the oil in floating state had low toxicity for fishes, nevertheless dispersed oil droplets had high toxicity and the toxicity of oil dued to the aromatic and naphthenic component contained in oil.

We compared the damage of environment caused by both floating oil layer and dispersed oil droplets and deduced as follows;

1. Spilled oil when abandoned as floating oil layer has low toxicity for fishes, but gives heavy damages to marine life on sea surface (laver or sloke) and the pollution of environment will continue for long period.

2. Spilled oil when treated by oil dispersers comes into sea water as fine oil droplets which have high toxicity for fishes but the damages of marine life on sea surface are controlled locally and the pollution of environment will discontinue in short period by natural digestions. 